\title{
PPAR $\gamma$ signaling exacerbates mammary gland tumor development
}

\author{
Enrique Saez, ${ }^{1,4}$ John Rosenfeld, ${ }^{1,5}$ Antonia Livolsi, ${ }^{2}$ Peter Olson, ${ }^{3}$ Eleuterio Lombardo, ${ }^{1}$ \\ Michael Nelson, ${ }^{1}$ Ester Banayo, ${ }^{1}$ Robert D. Cardiff, ${ }^{2}$ Juan Carlos Izpisua-Belmonte, ${ }^{1}$ and \\ Ronald M. Evans ${ }^{1,6}$ \\ ${ }^{1}$ The Salk Institute for Biological Studies, and Howard Hughes Medical Institute, La Jolla, California 92037, USA; ${ }^{2}$ Center \\ for Comparative Medicine, Department of Pathology, University of California, Davis, California 95616, USA; ${ }^{3}$ Department \\ of Biology, University of California, San Diego, La Jolla, California 92037, USA
}

\begin{abstract}
Breast cancer cell lines that express the nuclear peroxisome proliferator-activated receptor $\gamma(\operatorname{PPAR} \gamma)$ can be prompted to undergo growth arrest and differentiation when treated with synthetic PPAR $\gamma$ ligands. To evaluate the therapeutic potential of increased PPAR $\gamma$ signaling in vivo, we generated transgenic mice that express a constitutively active form of PPAR $\gamma$ in mammary gland. These mice are indistinguishable from their wild-type littermates. However, when bred to a transgenic strain prone to mammary gland cancer, bigenic animals develop tumors with greatly accelerated kinetics. Surprisingly, in spite of their more malignant nature, bigenic tumors are more secretory and differentiated. The molecular basis of this tumor-promoting effect may be an increase in Wnt signaling, as ligand activation of PPAR $\gamma$ potentiates Wnt function in an in vivo model of this pathway. These results suggest that once an initiating event has taken place, increased PPAR $\gamma$ signaling serves as a tumor promoter in the mammary gland.
\end{abstract}

[Keywords: PPAR $\gamma$; nuclear receptor; breast cancer; mammary tumors; Wnt signaling]

Supplemental material is available at http://www.genesdev.org.

Received November 5, 2003; revised version accepted January 29, 2004.

Peroxisome proliferator-activated receptors (PPARs) are members of the nuclear hormone receptor superfamily, ligand-responsive transcription factors that participate in many important physiological processes (Willson et al. 2000). Mammals have three different PPARs (PPAR $\alpha$, $\operatorname{PPAR} \delta, \operatorname{PPAR} \gamma$ ) that form functional heterodimers with the retinoid receptor RXR. These complexes are chief regulators of lipid storage and catabolism. Native and oxidized polyunsaturated fatty acids bind the PPARs and stimulate their transcriptional activity. The function of the PPARs is also modulated by arachidonic acid derivatives, such as prostaglandins and eicosanoids.

PPAR $\gamma$ is the best-characterized member of the family. Its most prominent role is to regulate differentiation of cell types with active lipid metabolism, such as adipocytes and macrophage foam cells (Rosen and Spiegelman 2001; Walczak and Tontonoz 2002). The importance of this receptor in lipid homeostasis and energy balance is accentuated by the widespread use of thiazolidinediones (TZDs), synthetic PPAR $\gamma$ ligands, as antidiabetic drugs. The existence of FDA-approved PPAR $\gamma$ agonists and the

Present addresses: ${ }^{4}$ Genomics Institute of the Novartis Research Foundation, San Diego, California 92121, USA; ${ }^{5}$ Department of Functional Genomics, Chemicon International, Temecula, California 92590, USA. ${ }^{6}$ Corresponding author.

E-MAIL evans@salk.edu; FAX (858) 455-1349.

Article and publication are at http://www.genesdev.org/cgi/doi/10.1101/ gad.1167804 ability of this receptor to induce cellular differentiation encouraged us to explore whether stimulation of PPAR $\gamma$ activity could curtail malignant cell growth, in analogy with what is observed with retinoic acid in acute promyelocytic leukemia.

A survey of tumors revealed that PPAR $\gamma$ is generally overexpressed in liposarcoma, colon, breast, and prostate carcinoma (Tontonoz et al. 1997; DuBois et al. 1998). When treated with PPAR $\gamma$ and RXR ligands, cell lines derived from these neoplasms undergo morphological transformation and growth arrest in vitro (Tontonoz et al. 1997; Elstner et al. 1998; Kubota et al. 1998; Mueller et al. 1998; Sarraf et al. 1998). Additional cell culture studies have suggested that lung, pancreatic, and hematopoietic tumor cells also respond to thiazolidinedione treatment (Sporn et al. 2001). These observations prompted trials to evaluate PPAR $\gamma$ agonists as therapeutics in human liposarcoma, colon, breast, and prostate cancer. Although the clinical outcome remains to be determined, initial results showed that in patients with advanced liposarcoma, the PPAR $\gamma$ ligand troglitazone was able to spur signs of differentiation, raising the possibility that in the appropriate context, the PPAR $\gamma$-signaling cascade could provide a new avenue of pharmacological intervention in neoplastic disease (Demetri et al. 1999).

However, the healing potential of PPAR $\gamma$ agonists in cancer has been questioned by our work and that of oth- 
ers showing that treatment of mice predisposed to colon cancer (the $A P C^{M i n}$ model) with PPAR $y$ ligands results in a dramatic increase in the number of tumors (Lefebvre et al. 1998; Saez et al. 1998). These unexpected results mimic what is seen when $A P C^{M i n}$ mice are fed a high-fat diet, suggesting that PPAR $\gamma$ activation may be a molecular link between a high-fat diet and increased risk of colorectal cancer (Wasan et al. 1997). A diet rich in certain fats is thought to increase the likelihood of colon, breast, and prostate cancer, but the mechanism whereby dietary fats enhance tumorigenesis is unknown. Because the PPARs sense the levels of dietary lipids and modify gene expression accordingly, it is possible that PPAR activation may be a functional link between fat and cancer promotion.

Much controversy has revolved around the discrepancy between the anticancer effects suggested by in vitro studies, and the tumor-promoting activity of PPAR $\gamma$ ligands evidenced by mouse models of colon cancer (Seed 1998). An explanation for this difference may be that cell-culture studies are not accurate representations of the complex interactions that lead to tumor formation in vivo. However, the issue is complicated, as treatment of rats with a PPAR $\gamma$ ligand induced regression of NMUinduced mammary carcinomas (Suh et al. 1999). Examination of many in vitro studies reveals that antiproliferative effects are often observed only at doses of PPAR $\gamma$ ligand orders of magnitude above the saturation level of the receptor. A growth-inhibition effect of PPAR $\gamma$ ligands has even been noted in cells that do not express $\operatorname{PPAR} \gamma$, questioning the identity of the mediator of this phenomenon (Abe et al. 2002). Experiments using cells derived from PPAR $\gamma$ null embryos have shown that PPAR $\gamma$ agonists have antiproliferative and anti-inflammatory effects on cells that lack the receptor (Chawla et al. 2001; Moore et al. 2001; Palakurthi et al. 2001). Thus, the anticancer effects ascribed to PPAR $\gamma$ ligands may not be due to enhanced PPAR $\gamma$ signaling, but rather, to the influence of an undiscovered action of the ligands.

To avoid the problem of receptor-independent effects caused by treatment with PPAR $\gamma$ ligands, we have taken a genetic approach to explore the intrinsic role of PPAR $\gamma$ signaling in another nutritionally sensitive tumor, breast cancer. To discern the contribution of PPAR $\gamma$ itself to this fat-susceptible cancer, we have generated transgenic mice that express a constitutively active form of PPAR $\gamma$ in mammary tissue. These mice are indistinguishable from their wild-type littermates, but when bred to a transgenic strain prone to mammary gland cancer, bigenic animals develop tumors with accelerated kinetics. These results indicate that once an initiating event has taken place, increased PPAR $\gamma$ signaling exacerbates mammary gland tumor development.

\section{Results}

PPAR $\gamma$ activation does not alter mammary gland development

To assess the effect of PPAR $\gamma$ signaling in cancer without using a ligand that could influence additional path- ways, a constitutively active mutant of PPAR $\gamma$ was created by fusing the activation domain of the herpes simplex virus Vp16 protein to the $\gamma 1$ isoform of PPAR $\gamma$. This mutant (VpPPAR $\gamma$ ) can transactivate a PPAR reporter to a similar magnitude as to what is observed with the natural receptor in the presence of ligand (Fig. 1A). VpPPAR $\gamma$ only signals through PPAR pathways; DNAbinding affinity studies and transfections in MCF7 and CV1 cells showed that VpPPAR $\gamma$ fails to regulate nonPPAR targets, such as reporters for the nuclear receptors VDR, TR, ER, FXR, and RAR. The finding that VpPPAR $\gamma$ does not interfere with estrogen or retinoid signaling is of significance, for these pathways play important roles in mammary gland development and neoplasia (Fig. 1B,C).

The effect of mammary-specific VpPPAR $\gamma$ expression was evaluated by generating transgenic mice expressing this mutant under the control of the mouse mammary tumor virus (MMTV) promoter. As measured by Northern analysis, expression of the transgene in mammary gland was weak in all lines, but the transgenic message was readily detected in epididymis, where the MMTV promoter is more active. MMTV-VpPPAR $\gamma$ mice are

A

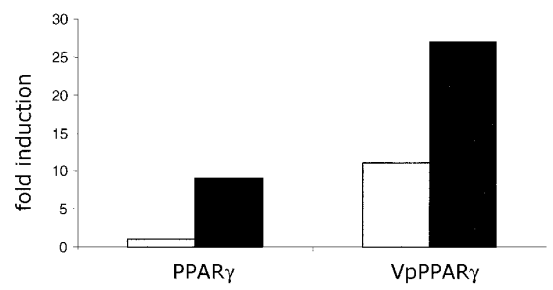

B
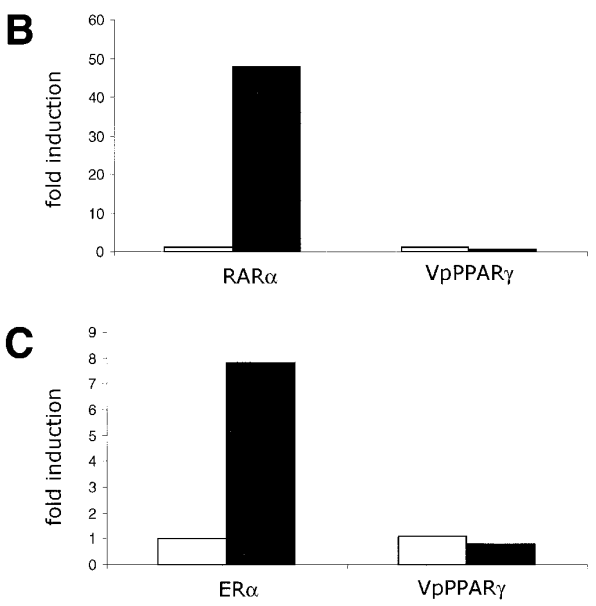

Figure 1. VpPPAR $\gamma$ faithfully mimics ligand-activated PPAR $\gamma$ signaling. (A) Cells were transfected with a reporter for PPAR activity (PPRE-tk-luc) and wild-type PPAR $\gamma$ or VpPPAR $\gamma$. Twenty-four hours after transfection, ligand was added $(1 \mu \mathrm{M}$ $\mathrm{BRL}$, black bars); cells were harvested 24 h later. (B) VpPPAR $\gamma$ does not signal through a retinoid response element. Cells were transfected with $\beta$-RARE-tk-luc and either RAR $\alpha$ or VpPPAR $\gamma$. All-trans retinoic acid (100 nM, black bars) was added $24 \mathrm{~h}$ later, and cells were harvested $48 \mathrm{~h}$ posttransfection. (C) VpPPAR $\gamma$ does not interfere with estrogen signaling. Cells were transfected with an estrogen-reponsive reporter (ERE-tk-luc) and either ER $\alpha$ or VpPPAR $\gamma$. Estradiol (100 nM, black bars) was added $24 \mathrm{~h}$ posttransfection, and cells were harvested $24 \mathrm{~h}$ later. 
morphologically identical to their wild-type littermates. Whole-mount analysis of mammary fat pads from sexually mature transgenic females showed that expression of the VpPPAR $\gamma$ mutant does not result in developmental anomalies; the degree of ductal outgrowth, branching, and alveolar proliferation is the same as that seen in wild-type glands (data not shown). Transgenic females are fertile and able to raise large litters; no mammary gland abnormalities were observed in numerous multiparous females monitored for more than a 16-mo span. A single mammary adenocarcinoma was noted in a pentaparous female at 20 mo of age, who also had myeloid leukemia. These observations indicate that low-level constitutive PPAR $y$ signaling does not interfere with normal mammary gland development, differentiation, or function.

\section{PPAR $\gamma$ signaling accelerates mammary tumor development}

To assess the therapeutic potential of increased PPAR $\gamma$ signaling in mammary gland neoplasia, tumor formation in MMTV-VpPPAR $\gamma$ animals was induced by breeding them to the MMTV-PyV strain. Expression of polyoma virus middle $\mathrm{T}$ antigen in the mammary gland of MMTV-PyV transgenics results in the rapid appearance of multifocal adenocarcinomas (Guy et al. 1992). In contrast to other strains expressing activated oncogenes in mammary epithelium, tumors in MMTV-PyV mice arise swiftly, with complete penetrance, and pervasive lung metastasis.

Offspring resulting from crossing the MMTVVpPPAR $\gamma$ and PyV transgenics were palpated biweekly from the time of weaning to monitor the emergence of lumps. Tumorigenesis experiments were carried out with virgin mice heterozygous for one or both transgenes. Animals were examined for more than $12 \mathrm{mo}$. No tumors were detected in wild-type $(n=23)$ or MMTV$\operatorname{VpPPAR} \gamma$ mice $(n=29)$ derived from these crosses, corroborating the finding that constitutive PPAR $\gamma$ activation has no deleterious effects in mammary gland under normal circumstances. In contrast, MMTV-PyV females developed tumors quickly, with an average time to detection of $57 \mathrm{~d}$ (Fig. 2A). Surprisingly, bigenic PyV/ $\operatorname{VpPPAR} \gamma$ females developed tumors with greatly accelerated kinetics, with a mean time to tumor appearance of only $37 \mathrm{~d}$ (Fig. 2A). Animals as young as $27 \mathrm{~d}$ were found bearing obvious palpable masses, a striking finding given that female mice reach maturity at $\sim 30 \mathrm{~d}$ of age. Bigenic mice were easily discernible from their littermates; at a time when tumors could only be palpated in one or two glands in MMTV-PyV mice, the entire mammary epithelium of bigenic animals was already transformed (Fig. 2C). Increased tumor burden reduced the survival time of MMTV-PyV/VpPPAR $\gamma$ females as compared with that of their MMTV-PyV siblings (91 vs. 116 d; Fig. 2B).

To evaluate whether increased PPAR $\gamma$ signaling promotes tumor development independent of hormonal influences, male offspring from MMTV-PyV $\times$ MMTV-
VpPPAR $\gamma$ crosses were studied. In our background, $79 \%$ of MMTV-PyV males (19 of 24) developed mammary adenocarcinomas, with a mean latency of $192 \mathrm{~d}$ (Fig. 3A). In contrast, tumors were detected in all bigenic PyV/ VpPPAR $\gamma$ males (22 of 22), with an average time to detection of only $114 \mathrm{~d}$. Bigenic males had a mean survival time of $191 \mathrm{~d}$, whereas their PyV littermates lived an average of $278 \mathrm{~d}$ (Fig. 3B). No abnormalities were noticed in 24 males carrying only the MMTV-VpPPAR $\gamma$ transgene. These results demonstrate that PPAR $\gamma$ activation in normal mammary epithelium is innocuous, but that once a tumor-initiating event takes place, PPAR $\gamma$ signaling acts as a strong tumor promoter in the mammary gland.

Bigenic tumors express higher levels of markers of differentiation and malignancy

Tumors from MMTV-PyV and MMTV-PyV/VpPPAR $\gamma$ mice were collected at the time of sacrifice. Pulmonary metastases were found in the majority of animals examined, irrespective of genotype. Histopathology of tumors revealed that whereas many bigenic tumors shared the characteristics of PyV-induced mammary adenocarcinomas (poorly differentiated neoplasms composed of solid sheets and nests of cells with large pleomorphic nuclei and scant cytoplasm, with a high mitotic rate and areas of focal necrosis), a significant proportion of $\mathrm{PyV} /$ VpPPAR $\gamma$ tumors were more secretory and differentiated (with neoplastic cells showing a pale pink cytoplasm containing numerous vacuoles; Fig. 4). This increased level of differentiation was evidenced by increased expression of markers such as carbonic anhydrase 2 and mucin 1 (Fig. 5B).

In contrast to the weak expression of the VpPPAR $\gamma$ transgene in unperturbed mammary gland, the transgenic message was detected with ease in bigenic tumors, perhaps because the proportion of epithelial cells (where the MMTV promoter is active) in transformed mammary gland is much greater than in the normal mammary pad, which is composed primarily of adipose cells. Northern analysis of RNA derived from PyV and bigenic tumors demonstrated that the VpPPAR $\gamma$ mutant behaves as expected, regulating the expression of known PPAR $\gamma$ target genes (e.g., aP2, CD36) in vivo in a physiologic manner (Fig. 5A). An explanation for the observed tumor-promoting effect of constitutive PPAR $\gamma$ activation could be that expression of VpPPAR $\gamma$ simply increases the levels of the oncogenic PyV transgene. This is not the case, for all tumors show similar levels of polyoma virus middle $\mathrm{T}$ antigen (Fig. 5A). Profiling analysis of RNA from tumors indicated that bigenic tumors express higher levels of several angiogenic factors and proteins linked with cancer progression (such as mucin 1, gravin, osteopontin, calgranulin $\mathrm{A}$, cystatin $\mathrm{C}$, and $\mathrm{PGE}_{2}$ synthase; Fig. $5 \mathrm{~B}$ ). For example, elevated levels of the protease cathepsin $\mathrm{L}$, a gene overexpressed in bigenic tumors, have been associated with increased tumor burden and decreased survival in human breast carcinoma (Foekens et al. 1998; Harbeck et al. 2000). 

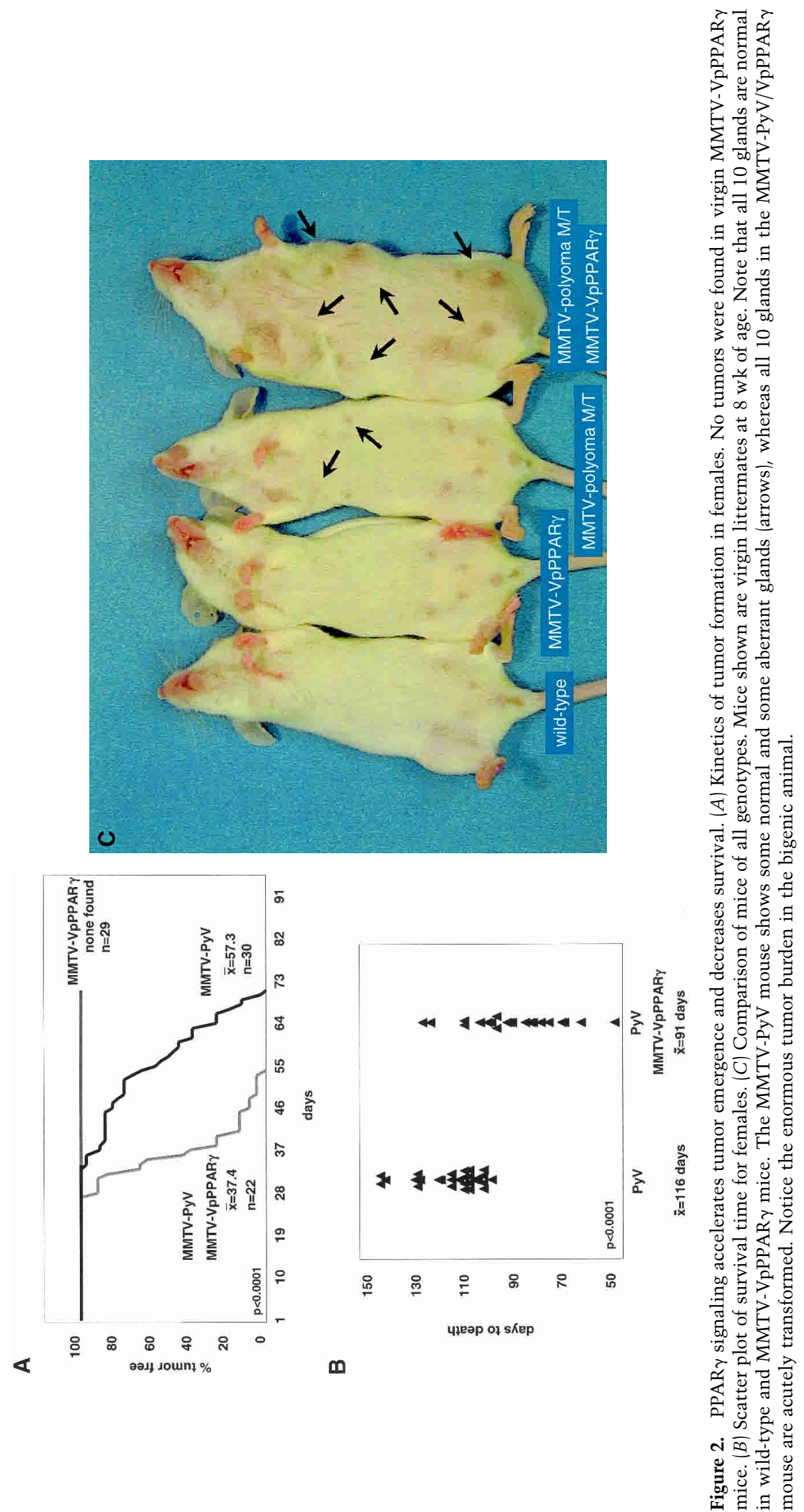


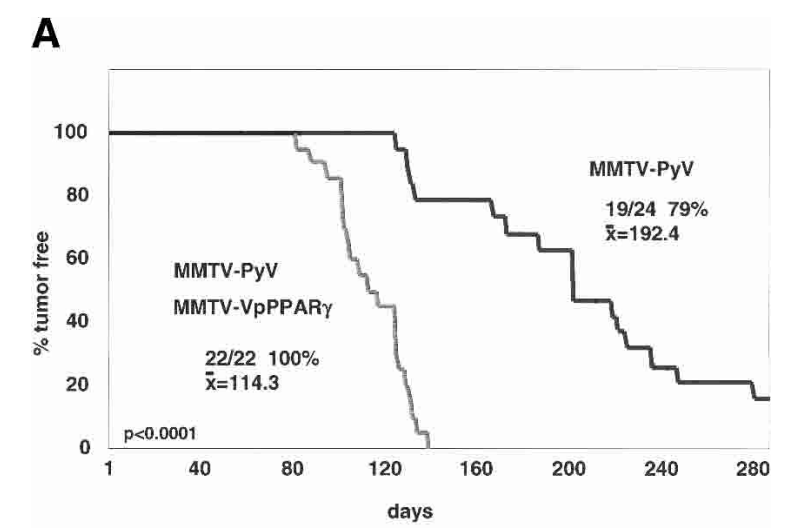

B

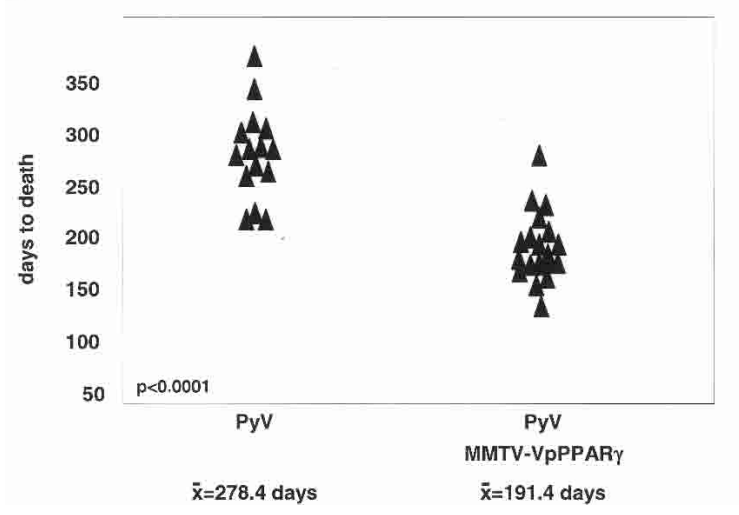

Figure 3. PPAR $\gamma$ activation hastens breast tumorigenesis in males. (A) Kinetics of tumor formation in males. Tumor penetrance was complete in bigenic mice, but not in MMTV-PyV males. $(B)$ Scatter plot of survival time for males.

\section{Loss of one allele of PPARy does not influence breast tumor development}

To balance our gain-of-function studies, we examined mammary gland tumor development in the context of reduced PPAR $\gamma$ signaling. Mice lacking PPAR $\gamma$ die in utero of placental defects, but heterozygotes are viable and fertile. These animals were bred to the MMTV-PyV model to evaluate mammary tumorigenesis in the absence of one PPAR $\gamma$ allele. MMTV-PyV transgenics with two copies of PPAR $\gamma$ developed tumors with an average latency of $72 \mathrm{~d}(n=30$; Fig. 6). In those carrying a single functional PPAR $\gamma$ allele, tumors became apparent with a mean onset of $76 \mathrm{~d}(n=14)$. The histology of tumors with reduced PPAR $\gamma$ dosage was similar to that of tumors with a full complement of PPAR $\gamma$. The absence of a significant difference in tumor incidence or pathology indicates that PPAR $y$ is not a tumor suppressor gene in mammary neoplasia, as has been suggested for other cancers. This finding is consistent with the fact that PPAR $\gamma$ is universally overexpressed in breast tumors (Fig. 5A; Gimble et al. 1998; Mueller et al. 1998; Ikezoe et al. 2001; Nwankwo and Robbins 2001).

\section{PPAR $\gamma$ activation potentiates Wnt signaling}

To understand how PPAR $\gamma$ might enhance tumor formation, we analyzed the impact of PPAR $\gamma$ activation in signaling pathways that play a causal role in both breast and colon carcinoma. A key signal transduction cascade implicated in the pathogenesis of these cancers is the Wnt pathway (Polakis 2000). Wnt signaling directs growth and patterning during embryonic development. In adults, it is thought to regulate stem-cell number in rapidly dividing epithelia, such as skin and intestine. Conserved from flies to mammals, Wnt signaling arose as an intercellular communication system that relies on a multitude of secreted ligands, ligand-sequestering factors, membrane-bound receptors, and intricate intracellular messenger cascades that control the activity of diverse nuclear targets (Taipale and Beachy 2001). Excessive Wnt signaling in adults leads to tumor formation; oncogenic mutations fix the pathway in a permanently activated state. The isolation of int-1 (wnt-1) as a gene activated by nearby integration of the MMTV virus in multiple mammary tumors marked the discovery of the Wnt pathway, but it was the study of human colon cancer that identified many of the intracellular components of Wnt signaling (Nusse and Varmus 1982; Kinzler and Vogelstein 1996).

Given the complexity of the Wnt pathway, cell-based transfection assays appear too limited to assess whether $\operatorname{PPAR} \gamma$ activation can influence Wnt signaling, as they measure stimulation of a single promoter out of physiological context. Moreover, because a single cell type is used, transfections cannot evaluate the multifaceted cell-cell interactions that are the basis of Wnt signaling. To circumvent these challenges, we used an in vivo vertebrate model system, the developing zebrafish embryo, to test the effect of PPAR $\gamma$ activation on Wnt signaling. In this system, RNA is injected into embryos and the phenotypic consequences of the introduced gene product

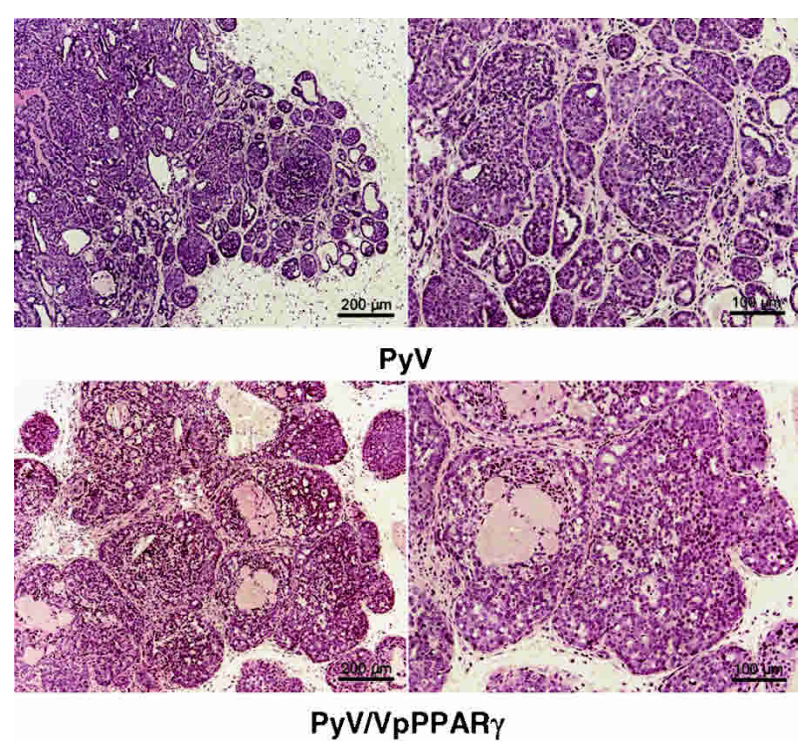

Figure 4. Histopathology of tumors. Hematoxylin and eosin staining of tumors harvested at the time of terminal sacrifice Genotype is as indicated. For pictures on the left, magnification is $10 \times$; for those on the right, magnification is $20 \times$. 

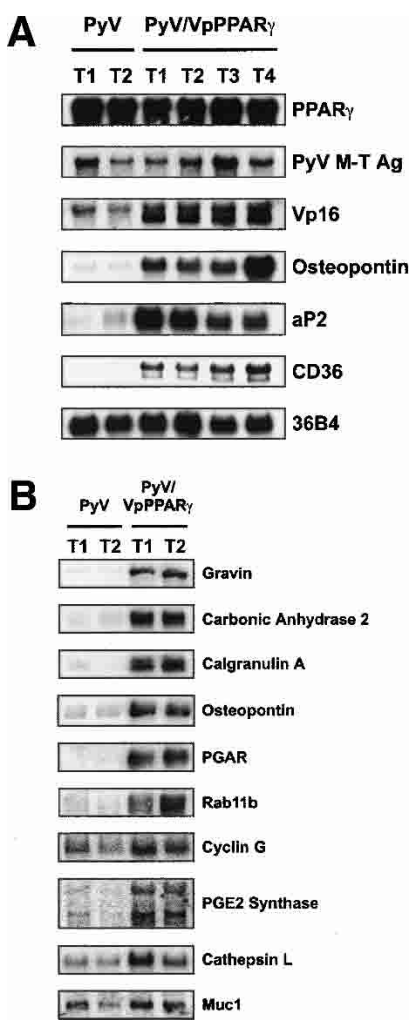

Figure 5. Northern analysis of RNA from tumors. (A) RNA was isolated from tumors at the time of sacrifice. Each lane represents an individual tumor of the indicated genotype. $(B)$ Multiple genes are overexpressed in bigenic tumors. Each lane contains RNA from a separate tumor. A ribosomal RNA-binding protein probe (36B4) was used as a loading control.

can be seen in a few hours in the context of the whole organism.

To determine whether PPAR $\gamma$ activation produces the same changes in early zebrafish development induced by overexpression of Wnt family members, zebrafish embryos were injected with synthetic RNAs encoding chicken Wnt8c, VpPPAR $\gamma$, polyoma virus middle $\mathrm{T}$ antigen, or mouse cyclin G1 (20-100 pg/embryo). GFP RNA was introduced with all RNAs as an injection control. As previously described, $80 \%-90 \%$ of zebrafish embryos injected with Wnt8c RNA (20 pg/embryo) failed to develop dorsoanterior structures, lacking either one or both eyes, and exhibiting forebrain, midbrain, and anterior hindbrain defects (Fig. 7; Kelly et al. 1995). Eyes that did develop in Wnt8c-injected embryos were notably smaller than those in uninjected or GFP-injected embryos. No abnormalities were observed in embryos injected with $100 \mathrm{pg}$ of GFP RNA. Embryos injected with the constitutively active PPAR $\gamma$-signaling mutant RNA (30-100 pg/embryo) showed a similar phenotype to that observed in Wnt8c-injected embryos; they lacked anterior structures, including eyes, forebrain, and midbrain ( $70 \%$ of injected embryos). Injection of $30-100 \mathrm{pg}$ of polyoma virus middle $\mathrm{T}$ antigen RNA also induced forebrain and eye defects in a high proportion of embryos $(50 \%-$ $60 \%$ ). In contrast, injection of RNA for cyclin G1, a
PPAR $\gamma$ target gene (E. Saez, S. Joseph, R.M. Evans, and P. Tontonoz, unpubl.) that we thought might be a mediator of the tumor-promoting effect of PPAR $\gamma$, did not induce abnormalities. These results suggest that PPAR $\gamma$ and polyoma virus middle $\mathrm{T}$ antigen can positively regulate Wnt signaling.

To examine the selectivity of the boost on Wnt signaling induced by PPAR $\gamma$ activation, zebrafish embryos were injected with wild-type PPAR $\gamma(100 \mathrm{pg} / \mathrm{embryo})$ and allowed to develop in the presence or absence of the synthetic PPAR $\gamma$ ligand rosiglitazone (BRL) at a dose (1 $\mu M)$ at which only receptor-dependent effects are observed. PPAR $\gamma$-injected embryos cultured in the absence of ligand developed normally, but $60 \%-70 \%$ of those incubated in the presence of rosiglitazone exhibited identical defects on eye and dorsoanterior development as embryos injected with Wnt8c, VpPPAR $\gamma$, or polyoma middle $\mathrm{T}$ antigen (Fig. 7). GFP-injected embryos cultured in the presence of the PPAR $\gamma$ ligand developed normally. These results indicate that natural PPAR $\gamma$ potentiates Wnt signaling in a ligand-dependent fashion. Moreover, PPAR $\gamma$ may be the only PPAR with the ability to positively modulate Wnt signaling, as injection of VpPPAR $\alpha$ or VpPPAR $\delta$ (as well as the Vp16 domain alone) did not elicit Wnt-like developmental defects (data not shown).

To ensure that the the dorsoanterior defects brought about by PPAR $\gamma$ activation were the result of increased Wnt signaling, the expression of Wnt target genes was examined. In zebrafish, the Wnt pathway patterns the future mesoderm by activating the expression of mesodermal organizing genes such as goosecoid (gsc) and no tail (ntl; Schulte-Merker et al. 1994a,b). To determine whether PPAR $\gamma$ signaling leads to activation of Wnt target genes, we monitored the expression of $n t l$ and $g s c$ in embryos at the onset of gastrulation $150 \%$ epiboly), $6 \mathrm{~h}$ after RNA injection. As expected, injec-

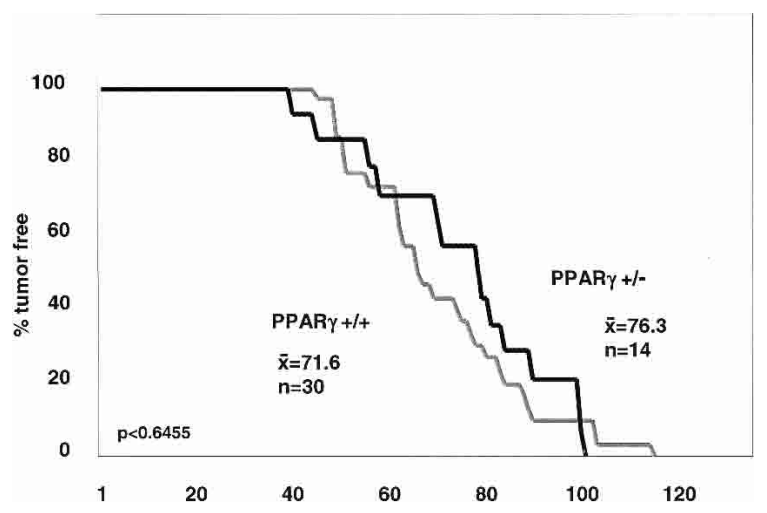

Figure 6. Reduced PPAR $\gamma$ dosage does not affect breast tumorigenesis. PPAR $\gamma$ heterozygous animals were bred to the MMTVPyV mouse to induce tumor development in the absence of one allele of PPAR $\gamma$. Data from virgin females is shown. The longer tumor latency in this setting (cf. Fig. 2A) is due to the different genetic background of the offspring resulting from the crosses of the PPAR $\gamma$ null allele to the PyV mouse, for the PPAR $\gamma$ heterozygous animals used were C57BL:129SvJ hybrids. 


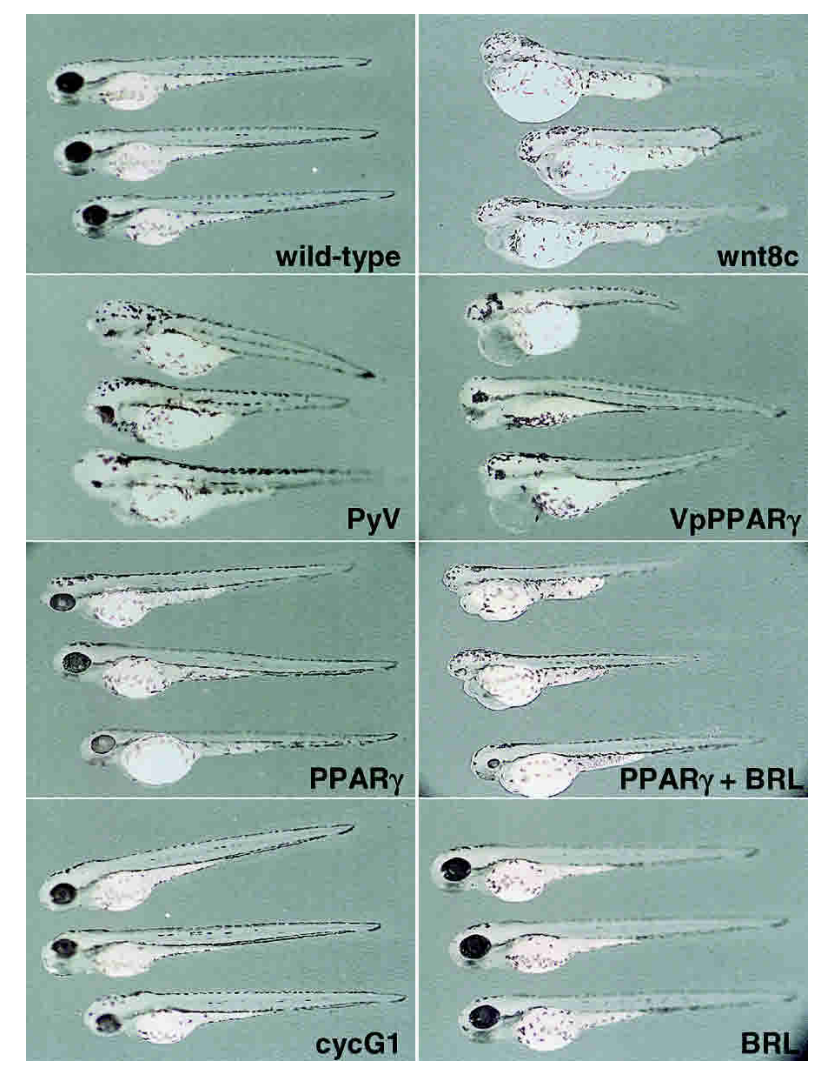

Figure 7. Phenotypic consequences of increased Wnt or PPAR $\gamma$ signaling in zebrafish. Single-cell zebrafish embryos were injected with the indicated RNA plus GFP RNA. GFPpositive embryos were sorted and fixed $3 \mathrm{~d}$ postinjection. The wild-type control represents embryos injected solely with GFP RNA. Note the complete loss of dorsoanterior structures and the eye defects in embryos injected with RNA encoding Wnt8c, $\operatorname{VpPPAR} \gamma$, polyoma middle $\mathrm{T}$ antigen, or natural PPAR $\gamma$ incubated in the presence of $1 \mu \mathrm{M}$ BRL. All other embryos appear normal.

tion of Wnt8c induced broadened and ectopic expression of $n t l$ at the germ ring of the zebrafish embryo (Fig. 8). Expression of ntl was similarly increased in embryos injected with $\operatorname{VpPPAR} \gamma$, natural $\operatorname{PPAR} \gamma$ cultured in the presence of ligand, and polyoma middle $\mathrm{T}$ antigen. In contrast, $n t l$ expression was not altered in embryos injected with cyclin G1, wild-type PPAR $\gamma$ cultured in the absence of ligand, or GFP-injected embryos incubated with rosiglitazone (Fig. 8). Analogous results were obtained when gsc expression was analyzed; $\operatorname{PPAR} \gamma$ activation prompted a broadening of the signal at the germ ring and $g s c$ expression outside of the shield, the same changes induced by Wnt8c injection (see Supplemental Material). The pattern of expression of $n t l$ and gsc, two Wnt targets, correlated perfectly with the phenotypes induced by the various RNAs injected. PPAR $\gamma$ activation, either by genetic or chemical means, led to increased expression of Wnt target genes and a functional phenotype indistinguishable from that induced by Wnt overexpression. These findings reveal that PPAR $\gamma$ signaling potentiates Wnt processes in vivo.

\section{Wnt target genes are overexpressed in MMTV-PyV/} VPPPAR y tumors

Because our observations in zebrafish suggested that enhanced Wnt signaling may constitute the basis of the tumor-promoting effect of PPAR $\gamma$ activation, the level of expression of Wnt target genes and various pathway components was profiled in MMTV-PyV and MMTV-PyV/VpPPAR $\gamma$ tumors using cDNA chip technology. Differences were verified using Northern blot and quantitative PCR. The expression of cyclin $D 1$ and $c-m y c$, the canonical mammalian Wnt target genes, was significantly up-regulated in multiple mammary tumors derived from bigenic females (Fig. 9A). The levels of PGE2 synthase were also uniformly increased. Among the pathway components examined, $\beta$-catenin itself was overexpressed in the majority of tumors studied, as was the Wnt receptor Frizzled homolog 4 (Fzd4). In contrast, the levels of wnt5a (but not wnt5b), and $F z d 9$ were down-regulated in PyV/VpPPAR $\gamma$ tumors (Fig. 9B). These findings support the notion that PPAR $\gamma$ activation can interfere with Wnt signaling and that it

\section{$n t l$ in situ hybridization - 6 hrs post-injection}
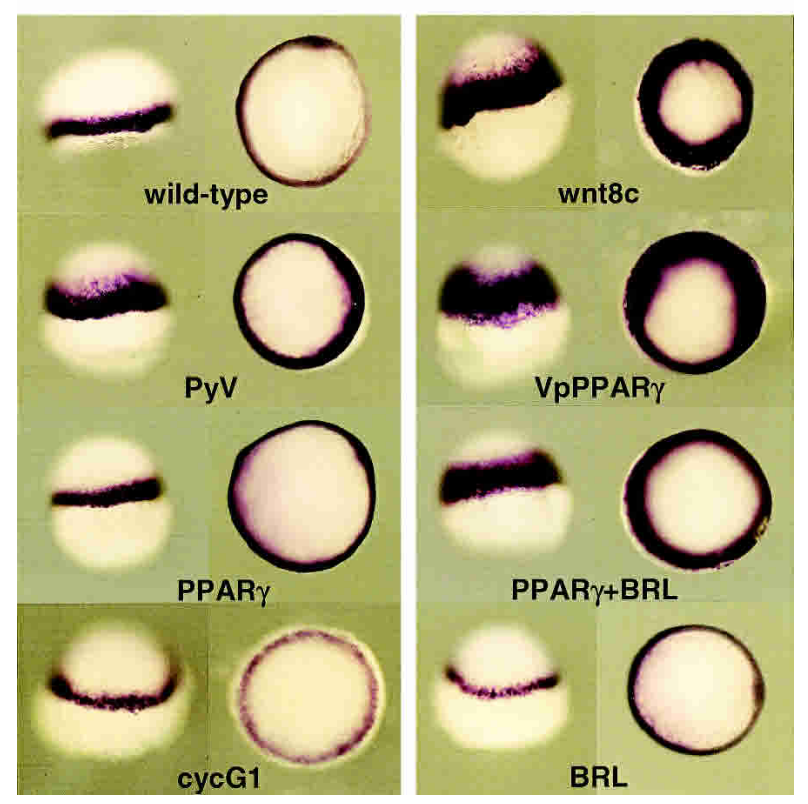

Figure 8. Expression of no tail in injected embryos. Injected single-cell embryos were processed for $n t l$ in situ hybridization at $50 \%-60 \%$ epiboly, $\sim 6 \mathrm{~h}$ postinjection. Embryos are shown in two orientations, a lateral view with the animal pole on top, and a view from the top looking down on the animal pole. Note the broadening of $n t l$ expression in the germ ring of embryos injected with RNA encoding Wnt8c, VpPPAR $\gamma$, polyoma middle $\mathrm{T}$ antigen, or natural PPAR $\gamma$ incubated in the presence of $1 \mu \mathrm{M}$ BRL. All other embryos displayed a normal pattern of $n t l$ expression. 
A

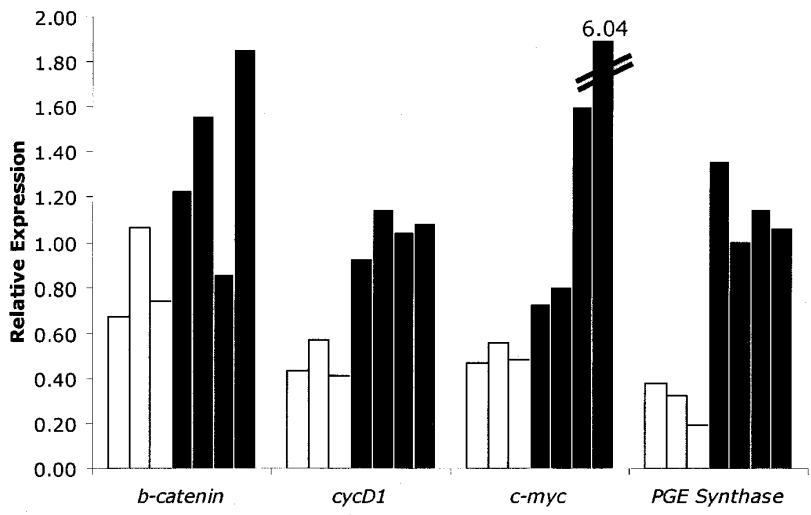

B

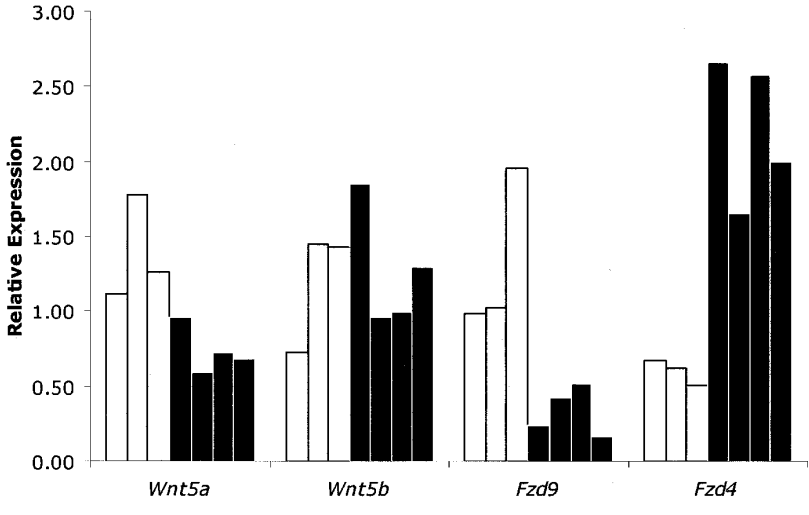

may promote tumor formation by increasing Wnt signaling.

\section{Discussion}

The emergence of a malignant tumor entails a host of events; cancer cells must acquire growth-factor independence, become insensitive to growth-constraining signals, elude apoptosis and replicative senescence, create a self-sustaining environment by secreting proteases and angiogenic factors, and escape the barriers imposed by their neighbors to migrate and colonize distant tissues (Hanahan and Weinberg 2000). The initial indication that the PPARs play a role in the etiology of cancer was the isolation of PPAR $\alpha$ as the mediator of the tumorpromoting effect of peroxisome proliferators, compounds that cause hepatocarcinomas in rodents (Corton et al. 2000). PPAR $\alpha$ is now known to be expressed in colon tumors and overexpressed in human breast and prostate cancer (Collett et al. 2000; Roberts-Thomson and Snyderwine 2000). The levels of PPAR $\delta$ are also elevated in colon and head and neck carcinomas (Gupta et al. 2000; Jaeckel et al. 2001). Absence of PPAR $\delta$ reduces tumor growth, and this PPAR may itself be a target of Wnt signaling (He et al. 1999; Park et al. 2001).

In contrast to the tumor-promotion associations of its siblings, PPAR $\gamma$ has become a potential target for the prevention and treatment of cancer (Sporn et al. 2001). But the promise of PPAR $\gamma$-based differentiation therapy has been questioned by work in animal models of colon cancer in which PPAR $\gamma$ ligands elicited an unanticipated
Figure 9. Expression of Wnt targets and Wnt pathway components in MMTV-PyV and MMTV-PyV/VpPPAR $\gamma$ tumors. RNA was isolated from tumors from PyV and MMTV-PyV/ VpPPAR $\gamma$ females and analyzed by quantitative PCR. All samples were run in triplicate and normalized to the internal control 36B4. To account for tumor-to-tumor variability in gene expression levels, each bar represents a single tumor. PyV tumors are shown as white bars (three tumors shown), whereas $\mathrm{PyV} / \mathrm{VpPPAR} \gamma$ bigenic tumors are represented as black bars (four tumors shown). (A) Canonical Wnt target genes such as $c y c D 1$ and $c$-myc are overexpressed in bigenic tumors. Note that the expression level of $c-m y c$ in the fourth bigenic tumor is off the scale shown. $\beta$-catenin and $P G E_{2}$ synthase are also uniformly up-regulated in tumors with genetic PPAR $\gamma$ activation. (B) Regulation of additional Wnt pathway components. Expression of Wnt5a and Fzd9 is significantly lower in bigenic tumors, whereas Fzd4 is overexpressed and Wnt $5 b$ unchanged. increase in tumors (Lefebvre et al. 1998; Saez et al. 1998). Interpretation of the actual role of PPAR $\gamma$ in cancer has been complicated by the recent finding that synthetic PPAR $\gamma$ ligands have effects on cell growth that are not dependent on the presence of PPAR $\gamma$ (Palakurthi et al. 2001; Clay et al. 2001, 2002; Place et al. 2003). The aim of this study was to examine solely the contribution of PPAR $\gamma$ signaling to the pathogenesis of breast cancer.

To evaluate the consequences of PPAR $\gamma$ activation and avoid the impact of PPAR $\gamma$ ligands on other pathways, we generated transgenic mice expressing low levels of a ligand-independent PPAR $\gamma$ mutant. Constitutive PPAR $\gamma$ signaling had no discernible effect on mammary gland differentiation or function. In contrast, enhanced PPAR $\gamma$ signaling on a background prone to breast cancer had striking consequences, accelerating tumor appearance and mortality in both females and males. In males, the penetrance of the phenotype also increased, underscoring the hormonal independence of the effect. Given the ability of polyoma middle $\mathrm{T}$ antigen to induce tumors with a very short latency, this tumor-induction synergy is remarkable, particularly in light of the feeble effect of the VpPPAR $\gamma$ transgene on its own. It is not clear why PPAR $\gamma$ signaling has different consequences in normal and initiated cells, but it is important to emphasize that this difference exists. A similar observation has been reported in colon, where the effect of PPAR $\gamma$ activation appears to depend on the APC status of the cells (Girnun et al. 2002).

Our results are inconsistent with one of the other few in vivo studies that has examined the ability of enhanced 
PPAR $\gamma$ signaling to restrain breast cancer (Suh et al. 1999). In that case, a PPAR $\gamma$ activator prevented the development in rats of NMU-induced mammary tumors. It is possible that the inhibition seen reflects $\operatorname{PPAR} \gamma$-independent effects of the ligand used. The transcription factor NF- $\mathrm{KB}$ has been shown to regulate proliferation of mammary epithelium and to be hyperactivated in human breast cancer (Rayet and Gelinas 1999; Cogswell et al. 2000; Brantley et al. 2001). Synthetic PPAR $\gamma$ activators are known to inhibit NF-кB activation, so it is conceivable that down-regulation of NF- $\mathrm{B}$ function may account for the tumor-stalling effect (Castrillo et al. 2001). Alternatively, as we examined the consequences of PPAR $\gamma$ activation exclusively in epithelial cells, the discrepancy in our results may indicate that activation of PPAR $\gamma$ in the stroma of the mammary fat pad (brought about by systemic ligand administration) results in paracrine inhibition of mammary epithelial cell proliferation. Interestingly, another study testing the efficacy of the thiazolidinedione troglitazone to inhibit DMBA-induced rat mammary carcinomas documented increases in tumor incidence, primary tumor volume, and total tumor volume in troglitazone-treated rats (Pighetti et al. 2001). Furthermore, a human trial using troglitazone as treatment for refractory breast cancer failed to uncover clinical value during the period of treatment (20 wk). All patients experienced disease progression, in some cases accompanied by elevated expression of tumor markers (Burstein et al. 2003). Unfortunately, a similar conclusion was drawn in a recent phase II trial using rosiglitazone in liposarcoma patients. In contrast to preliminary trials in which PPAR $\gamma$ ligands showed therapeutic promise, rosiglitazone was not an effective drug for the treatment of liposarcomas (Debrock et al. 2003).

Hemizygous loss-of-function mutations in PPAR $\gamma$ have been identified in colon and prostate carcinoma (Sarraf et al. 1999; Mueller et al. 2000), leading to the suggestion that PPAR $\gamma$ may function as a tumor suppressor in diet-sensitive tumors (Akiyama et al. 2001). However, these reports are at odds with a survey of $397 \mathrm{hu}-$ man tumors that failed to find a single mutation in PPAR $\gamma$ (Ikezoe et al. 2001). Furthermore, because tumors universally express higher levels of PPAR $\gamma$ than normal tissue, it is hard to envision how $\operatorname{PPAR} \gamma$ can fit the Knudson definition of a tumor suppressor gene (Knudson 2001). We find that reduced PPAR $\gamma$ dosage has no effect in mammary gland carcinogenesis; mice heterozygous for a null mutation develop tumors with the same kinetics as those carrying two functional copies. Our findings are supported by a recent study that used Cre-Lox technology to ablate PPAR $\gamma$ in the epithelial component of the mammary gland; no tumors arose in glands lacking PPAR y (Cui et al. 2002). PPAR $\gamma$ does not behave as a tumor suppressor in mammary gland. This is likely also the case in human breast, for new work has failed to find an association between the Pro12Ala PPAR $\gamma$ polymorphism (a mutation that results in decreased receptor activity) and incidence of breast cancer (Memisoglu et al. 2002). Moreover, a similar observation has recently been reported in a cohort of Finnish males; the Pro12Ala
PPAR $\gamma$ polymorphism does not appear to play a role in prostate cancer risk in this population (Paltoo et al. 2003).

To understand at the molecular level how PPAR $\gamma$ activation in an initiated tissue promotes neoplasia, we tested the possibility that PPAR $\gamma$ signaling could modulate the Wnt pathway. Enhanced Wnt signaling is common in familial and sporadic colon and breast tumors (Bienz and Clevers 2000). To examine whether PPARy can interfere with Wnt signaling in the organism, we used zebrafish. This in vivo system is a robust tool to evaluate the impact of exogenous genes on entire genetic networks. We found that PPAR $\gamma$ activation elicited the same phenotypic aberrations and up-regulation of endogenous Wnt target genes as overexpression of Wnt ligands that positively regulate the pathway.

The specificity of this effect was corroborated by the fact that wild-type PPAR $\gamma$ could only induce these changes in the presence of ligand. The other gene tested that also caused Wnt-like defects was polyoma virus middle $\mathrm{T}$ antigen. Transformation of mammalian cells by middle $\mathrm{T}$ antigen requires association of this protein with the protein phosphatase $2 \mathrm{~A}$ complex (PP2A), where it substitutes for one of the regulatory subunits (Pallas et al. 1990; Glover et al. 1999|. The catalytic subunit of $\mathrm{PP} 2 \mathrm{~A}$ is a positive regulator of Wnt signaling in vivo, so it is likely that middle $\mathrm{T}$ exerts its effects on Wnt signaling by enhancing PP2A activity (Ratcliffe et al. 2000). How PPAR $\gamma$ activation boosts Wnt signaling remains to be established, but because PPAR $\gamma$ is a transcription factor, it is possible that it may regulate the expression of a Wnt ligand, a receptor of the frizzled family, or a Wnt effector. Our data indicates that PPAR $\gamma$ down-regulates Wnt5a expression, a suggestive finding, for antisense Wnt5a mimics Wnt-1 mediated transformation of mammary cells (Olson and Gibo 1998). Additional study will be required to elucidate the details of the PPAR $\gamma-W n t$ signaling interaction. It is interesting to note that in colon, PPAR $\gamma$ is expressed primarily in cells of the proliferating crypt, not in the terminally differentiated surface epithelium (Saez et al. 1998). PPAR $\gamma$ expression in mammary gland is greatest in virgin glands, where it is associated with proliferating cells of the terminal end buds (T.N. Seagroves and J.M. Rosen, pers. comm.; Gimble et al. 1998). In these epithelial tissues, these are the cells in which Wnt signaling is thought to act to regulate the number of adult stem cells. PPAR $\gamma$-induced Wnt signaling in these cells could result in mis-specification of cell fate and an expansion of the stem-cell compartment that ultimately would render the organism more susceptible to cancer development.

Globalization of trends that characterize modern Western society, such as the prevalence of a sedentary lifestyle and the inexorable spread of obesity, has led to an astonishing increase in the incidence of type-2 diabetes worldwide (Zimmet et al. 2001). PPAR $\gamma$ activators are effective tools in the fight against the looming diabetes epidemic. It is possible that our observations in mice may not apply to humans. Activation of PPAR $\alpha$ by peroxisome proliferators in rodents induces liver tumors, 
yet these compounds do not promote cancer in humans, so the effect we have documented could also be species specific. Nonetheless, our findings highlight the need to conduct follow-up studies on diabetics treated with thiazolidinediones to clarify the influence of PPAR $\gamma$ activators on human cancer.

\section{Materials and Methods}

\section{Generation and analysis of transgenic animals}

A constitutively-active PPAR $\gamma$ mutant (VpPPAR $\gamma$ ) was generated by fusing the transcriptional activation domain of HSV Vp16 to the $\mathrm{N}$ terminus of mouse PPAR $\gamma 1$. The transactivation ability of VpPPAR $\gamma$ was assessed by transient transfection into CV1 and MCF7 cells. Transfections were performed multiple times in triplicate, using CMV- $\beta$-gal to control for transfection efficiency. Reporter and transactivator constructs were introduced and ligand was added $24 \mathrm{~h}$ later. Reporter activity was measured $24 \mathrm{~h}$ after ligand addition. The DNA-binding potential of VPPPAR $\gamma$ was established using EMSA and in vitro-translated proteins. The MMTV-VpPPAR $\gamma$ transgene was created by placing VpPPAR $\gamma$ in a vector containing the MMTV promoter/ enhancer and rabbit $\beta$-globin RNA-stabilizing elements (Pierce et al. 1995). Expression of the transgene was assessed by Northern analysis of RNA extracted from adult tissues. Whole-mount analysis of mammary glands taken from virgin mice at various phases of the reproductive cycle was performed as described (Seagroves et al. 1998).

\section{Tumor analysis}

MMTV-PyV animals were purchased from Jackson Labs (stock number 002374) and bred to MMTV-VpPPAR $\gamma$ transgenics or PPAR $\gamma$ null heterozygotes generated in our laboratory (Barak et al. 1999). Offspring were palpated biweekly in a blind manner from the time of weaning to detect tumors. Animals were sacrificed when tumor burden became excessive, and tissues harvested for histology and RNA analysis. Pathology and immunohistochemistry were performed at the UC Davis Mutant Mouse Pathology Laboratory. Statistical analysis of tumor kinetics was carried out by the Biostatistics Department at the UCSD Cancer Center.

\section{Zebrafish embryo studies}

Sequences encoding chicken Wnt8c, mouse PPAR $\gamma, \operatorname{VpPPAR} \gamma$, mouse cyclin $\mathrm{G} 1$, and polyoma virus middle $\mathrm{T}$ antigen were cloned into pCS2, and capped RNAs were transcribed from linearized plasmid DNAs using the SP6 mMessage mMachine kit (Ambion). Synthetic RNAs (20-100 pg/embryo) were injected into 1-2-cell zebrafish (Danio rerio) embryos obtained from natural matings as described (Detrich et al. 1999a,b). To identify properly injected embryos, 50 pg of GFP RNA were coinjected per embryo. Four hours postinjection, GFP-expressing embryos were selected by epifluorescent detection and fixed in $4 \%$ paraformaldehyde at chosen stages. RNA for each gene under evaluation was injected into a minimum of 500 embryos.

\section{Whole-mount in situ hybridization}

To analyze Wnt target gene expression, zebrafish embryos were injected with RNA and fixed $6 \mathrm{~h}$ postinjection by overnight incubation in $4 \%$ paraformaldehyde in PBS. After methanol de- hydration, embryos were processed for whole-mount in situ hybridization (Schulte-Merker et al. 1994b). Zebrafish gsc and $n t 1$ cDNAs (A. Schier, Skirball Institute) were used as templates to generate DIG-labeled probes.

\section{cDNA microarray profiling of tumors}

Tumors were isolated from male and female MMTV-PyV and MMTV-PyVpPPAR $\gamma$ mice. Total RNA from two tumors of each genotype was pooled, mRNA extracted, and first strand cDNAs labeled directly with $\mathrm{Cy} 3+\mathrm{Cy} 5$ containing nucleotides as described previously (Rosenfeld et al. 2003). Custom cDNA microarray slides were spotted in duplicate by the Salk Institute Functional Genomics Core containing 8700 GEM-5214 sequence-verified IMAGE Consortium EST cDNA clones. Additional clones included select sequence-verified cDNAs representing members of the Wnt pathway. The entire clone content of the array is available in Supplementary Table 1. Equimolar mixtures of $\mathrm{Cy} 3+\mathrm{Cy} 5$ probes were hybridized and analyzed using fluorophore reversal; data was acquired and filtered as previously described (Rosenfeld et al. 2003)

\section{Quantitation of gene expression}

Tumor-derived RNA was DNase I treated and the DNase I was inactivated using DNase I inactivating reagent (Ambion). A total of $100 \mathrm{ng}$ were reverse transcribed and cDNA was subsequently RNase treated. cDNA was diluted 1:4, 1:10, 1:25, 1:100, and 1:250 to generate a standard curve, and samples were diluted 1:20. Q-PCR samples were run in triplicate in $15-\mu \mathrm{L}$ reactions using Taqman Master Mix (Applied Biosystems). Values were normalized to levels of 36B4. Oligos: Fzd9 forward, 5'GGCCACAGAGCAACCATGTAC-3'; Fzd9 reverse, 5'-CCC ACCACCAAGGACATGA-3'; PGE2 synthase forward, 5'-TG GGACCCAACCCTCTGAT-3'; PGE2 synthase reverse, 5'-C AGGTAGGCCACGGTGTGTA-3'; Wnt5a forward, 5'-CCAC GCTAAGGGTTCCTATGAG-3'; Wnt5a reverse, 5'-TGTC CTACGGCCTGCTTCA-3'; Wnt5b forward, 5-'CCACTGGT GTTGCTTTGTCAGA-3'; Wnt5b reverse, 5-'CGTGTGGTGC AGTCACTTACAGA-3'; $\beta$-catenin forward, 5'-CGTCCCC AGTTCCCATCAT-3'; $\beta$-catenin reverse, 5'-ACTACAACA GAAAAGGGTGTAATGGA-3'; $c y c D 1$ forward, $5^{\prime}$-GCTGCGA GCCATGCTCA-3'; cycD1 reverse, 5' -TTCTGCACGCACTTG AAGTAAGA-3'; 36 B4 forward, 5'-AGATGCAGCAGATCCG CAT-3'; 36 B $^{\prime}$ reverse, 5'-GTTCTTGCCCATCAGCACC-3'; $c$-myc forward, 5-'GGGTAGAGCGACTTGTCAAGATG-3'; c-myc reverse, 5'-GTCACGTCAGCCCATAGTAACCT-3'; Fzd4 forward, 5'-CACTCACCCAACTCAGCATCAG-3'; Fzd4 reverse, 5'-GGCTTTTCCATTTTGGACCAT-3' .

\section{Acknowledgments}

We thank Anton Tutter, Peter Tontonoz, Lazslo Nagy, Tiffany Seagroves, Jeff Rosen, Johan Auwerx, Lluis Fajas, Alex Schier, Betsy Gilpin, Ben Nicholson, and Yasuhiko Kawakami for reagents and helpful discussions. E.S. is a former fellow of the Susan G. Komen Breast Cancer Foundation. R.M.E. is an Investigator of the Howard Hughes Medical Institute at the Salk Institute and March of Dimes Chair in Molecular and Developmental Biology. This work was supported by the Susan G. Komen Breast Cancer Foundation, the Mathers Foundation, the Hilblom Foundation, and NIH Program Project CA54418.

The publication costs of this article were defrayed in part by payment of page charges. This article must therefore be hereby 
marked "advertisement" in accordance with 18 USC section 1734 solely to indicate this fact.

\section{References}

Abe, A., Kiriyama, Y., Hirano, M., Miura, T., Kamiya, H., Harashima, H., and Tokumitsu, Y. 2002. Troglitazone suppresses cell growth of KU812 cells independently of PPAR $\gamma$. Eur. J. Pharmacol. 436: 7-13.

Akiyama, T.E., Nicol, C.J., and Gonzalez, F.J. 2001. On par with PPARs. Trends Genet. 17: 310-312.

Barak, Y., Nelson, M.C., Ong, E.S., Jones, Y.Z., Ruiz-Lozano, P., Chien, K.R., Koder, A., and Evans, R.M. 1999. PPAR $\gamma$ is required for placental, cardiac, and adipose tissue development. Mol. Cell 4: 585-595.

Bienz, M. and Clevers, H. 2000. Linking colorectal cancer to Wnt signaling. Cell 103: 311-320.

Brantley, D.M., Chen, C.L., Muraoka, R.S., Bushdid, P.B., Bradberry, J.L., Kittrell, F., Medina, D., Matrisian, L.M., Kerr, L.D., and Yull, F.E. 2001. Nuclear factor-кB (NF-кB) regulates proliferation and branching in mouse mammary epithelium. Mol. Biol. Cell 12: 1445-1455.

Burstein, H.J., Demetri, G.D., Mueller, E., Sarraf, P., Spiegelman, B.M., and Winer, E.P. 2003. Use of the peroxisome proliferator-activated receptor (PPAR) $\gamma$ ligand troglitazone as treatment for refractory breast cancer: A phase II study. Breast Cancer Res. Treat. 79: 391-397.

Castrillo, A., Mojena, M., Hortelano, S., and Bosca, L. 2001. Peroxisome proliferator-activated receptor- $\gamma$-independent inhibition of macrophage activation by the non-thiazolidinedione agonist L-796,449. Comparison with the effects of 15-deoxy-delta(12,14)- prostaglandin J(2). J. Biol. Chem. 276: 34082-34088.

Chawla, A., Barak, Y., Nagy, L., Liao, D., Tontonoz, P., and Evans, R.M. 2001. PPAR- $\gamma$ dependent and independent effects on macrophage-gene expression in lipid metabolism and inflammation. Nat. Med. 7: 48-52.

Clay, C.E., Namen, A.M., Atsumi, G., Trimboli, A.J., Fonteh, A.N., High, K.P., and Chilton, F.H. 2001. Magnitude of peroxisome proliferator-activated receptor- $\gamma$ activation is associated with important and seemingly opposite biological responses in breast cancer cells. J. Investig. Med. 49: 413-420.

Clay, C.E., Monjazeb, A., Thorburn, J., Chilton, F.H., and High, E.P. 2002. 15-Deoxy- $\Delta^{12,14}$-prostaglandin $\mathrm{J}_{2}$-induced apoptosis does not require PPAR $\gamma$ in breast cancer cells. J. Lipid Res. 43: 1818-1828.

Cogswell, P.C., Guttridge, D.C., Funkhouser, W.K., and Baldwin Jr., A.S. 2000. Selective activation of NF-к B subunits in human breast cancer: Potential roles for NF-к B2/p52 and for Bcl-3. Oncogene 19: 1123-1131.

Collett, G.P., Betts, A.M., Johnson, M.I., Pulimood, A.B., Cook, S., Neal, D.E., and Robson, C.N. 2000. Peroxisome proliferator-activated receptor $\alpha$ is an androgen-responsive gene in human prostate and is highly expressed in prostatic adenocarcinoma. Clin. Cancer Res. 6: 3241-3248.

Corton, J.C., Lapinskas, P.J., and Gonzalez, F.J. 2000. Central role of PPAR $\alpha$ in the mechanism of action of hepatocarcinogenic peroxisome proliferators. Mutat. Res. 448: 139-151.

Cui, Y., Miyoshi, K., Claudio, E., Siebenlist, U.K., Gonzalez, F.J., Flaws, J., Wagner, K.U., and Hennighausen, L. 2002. Loss of the peroxisome proliferation-activated receptor $\gamma(\operatorname{PPAR} \gamma)$ does not affect mammary development and propensity for tumor formation but leads to reduced fertility. J. Biol. Chem. 277: 17830-17835.

Debrock, G., Vanhentenrijk, V., Sciot, R., Debiec-Rychter, M.,
Oyen, R., and Van Oosterom, A. 2003. A phase II trial with rosiglitazone in liposarcoma patients. Brit. I. of Cancer 89: 1409-1412.

Demetri, G.D., Fletcher, C.D., Mueller, E., Sarraf, P., Naujoks, R., Campbell, N., Spiegelman, B.M., and Singer, S. 1999. Induction of solid tumor differentiation by the peroxisome proliferator-activated receptor- $\gamma$ ligand troglitazone in patients with liposarcoma. Proc. Natl. Acad. Sci. 96: 3951-3956.

Detrich, H.W., Westerfield, M., Zon, L.I., and American Society for Cell Biology. 1999a. The Zebrafish: Biology. Academic Press, San Diego, CA.

-1999b. The Zebrafish: Genetics and genomics. Academic Press, San Diego, CA.

DuBois, R.N., Gupta, R., Brockman, J., Reddy, B.S., Krakow, S.L., and Lazar, M.A. 1998. The nuclear eicosanoid receptor, $\operatorname{PPAR} \gamma$, is aberrantly expressed in colonic cancers. Carcinogenesis 19: 49-53.

Elstner, E., Muller, C., Koshizuka, K., Williamson, E.A., Park, D., Asou, H., Shintaku, P., Said, J.W., Heber, D., and Koeffler, H.P. 1998. Ligands for peroxisome proliferator-activated receptor $\gamma$ and retinoic acid receptor inhibit growth and induce apoptosis of human breast cancer cells in vitro and in BNX mice. Proc. Nat1. Acad. Sci. 95: 8806-8811.

Foekens, J.A., Kos, J., Peters, H.A., Krasovec, M., Look, M.P., Cimerman, N., Meijer-van Gelder, M.E., Henzen-Logmans, S.C., van Putten, W.L., and Klijn, J.G. 1998. Prognostic significance of cathepsins $\mathrm{B}$ and $\mathrm{L}$ in primary human breast cancer. J. Clin. Oncol. 16: 1013-1021.

Gimble, J.M., Pighetti, G.M., Lerner, M.R., Wu, X., Lightfoot, S.A., Brackett, D.J., Darcy, K., and Hollingsworth, A.B. 1998. Expression of peroxisome proliferator activated receptor mRNA in normal and tumorigenic rodent mammary glands. Biochem. Biophys. Res. Commun. 253: 813-817.

Girnun, G.D., Smith, W.M., Drori, S., Sarraf, P., Mueller, E., Eng, C., Nambiar, P., Rosenberg, D.W., Bronson, R.T., Edelmann, W., et al. 2002. APC-dependent suppression of colon carcinogenesis by PPAR $\gamma$. Proc. Natl. Acad. Sci. 99: 1377113776.

Glover, H.R., Brewster, C.E., and Dilworth, S.M. 1999. Association between src-kinases and the polyoma virus oncogene middle T-antigen requires PP2A and a specific sequence motif. Oncogene 18: 4364-4370.

Gupta, R.A., Tan, J., Krause, W.F., Geraci, M.W., Willson, T.M., Dey, S.K., and DuBois, R.N. 2000. Prostacyclin-mediated activation of peroxisome proliferator-activated receptor $\delta$ in colorectal cancer. Proc. Natl. Acad. Sci. 97: 13275-13280.

Guy, C.T., Cardiff, R.D., and Muller, W.J. 1992. Induction of mammary tumors by expression of polyomavirus middle $\mathrm{T}$ oncogene: A transgenic mouse model for metastatic disease. Mol. Cell. Biol. 12: 954-961.

Hanahan, D. and Weinberg, R.A. 2000. The hallmarks of cancer. Cell 100: $57-70$

Harbeck, N., Alt, U., Berger, U., Kates, R., Kruger, A., Thomssen, C., Janicke, F., Graeff, H., and Schmitt, M. 2000. Longterm follow-up confirms prognostic impact of PAI-1 and cathepsin D and L in primary breast cancer. Int. J. Biol. Markers 15: 79-83.

He, T.C., Chan, T.A., Vogelstein, B., and Kinzler, K.W. 1999. PPARd is an APC-regulated target of nonsteroidal anti-inflammatory drugs. Cell 99: 335-345.

Ikezoe, T., Miller, C.W., Kawano, S., Heaney, A., Williamson, E.A., Hisatake, J., Green, E., Hofmann, W., Taguchi, H., and Koeffler, H.P. 2001. Mutational analysis of the peroxisome proliferator-activated receptor $\gamma$ gene in human malignancies. Cancer Res. 61: 5307-5310.

Jaeckel, E.C., Raja, S., Tan, J., Das, S.K., Dey, S.K., Girod, D.A., 
Tsue, T.T., and Sanford, T.R. 2001. Correlation of expression of cyclooxygenase-2, vascular endothelial growth factor, and peroxisome proliferator-activated receptor $\delta$ with head and neck squamous cell carcinoma. Arch. Otolaryngol. Head Neck Surg. 127: 1253-1259.

Kelly, G.M., Greenstein, P., Erezyilmaz, D.F., and Moon, R.T. 1995. Zebrafish wnt 8 and wnt 8 b share a common activity but are involved in distinct developmental pathways. Development 121: 1787-1799.

Kinzler, K.W. and Vogelstein, B. 1996. Lessons from hereditary colorectal cancer. Cell 87: 159-170.

Knudson, A.G. 2001. Two genetic hits (more or less) to cancer. Nat. Rev. Cancer 1: 157-162.

Kubota, T., Koshizuka, K., Williamson, E.A., Asou, H., Said, J.W., Holden, S., Miyoshi, I., and Koeffler, H.P. 1998. Ligand for peroxisome proliferator-activated receptor $\gamma$ (troglitazone) has potent antitumor effect against human prostate cancer both in vitro and in vivo. Cancer Res. 58: 3344-3352.

Lefebvre, A.M., Chen, I., Desreumaux, P., Najib, J., Fruchart, J.C., Geboes, K., Briggs, M., Heyman, R., and Auwerx, J. 1998. Activation of the peroxisome proliferator-activated receptor $\gamma$ promotes the development of colon tumors in C57BL/6J-APCMin/+ mice. Nat. Med. 4: 1053-1057.

Memisoglu, A., Hankinson, S.E., Manson, J.E., Colditz, G.A., and Hunter, D.J. 2002. Lack of association of the codon 12 polymorphism of the peroxisome proliferator-activated receptor $\gamma$ gene with breast cancer and body mass. Pharmacogenetics 12: 597-603.

Moore, K.J., Rosen, E.D., Fitzgerald, M.L., Randow, F., Andersson, L.P., Altshuler, D., Milstone, D.S., Mortensen, R.M., Spiegelman, B.M., and Freeman, M.W. 2001. The role of PPAR- $\gamma$ in macrophage differentiation and cholesterol uptake. Nat. Med. 7: 41-47.

Mueller, E., Sarraf, P., Tontonoz, P., Evans, R.M., Martin, K.J., Zhang, M., Fletcher, C., Singer, S., and Spiegelman, B.M. 1998. Terminal differentiation of human breast cancer through PPAR $\gamma$. Mol. Cell 1: 465-470.

Mueller, E., Smith, M., Sarraf, P., Kroll, T., Aiyer, A., Kaufman, D.S., Oh, W., Demetri, G., Figg, W.D., Zhou, X.P., et al. 2000. Effects of ligand activation of peroxisome proliferator-activated receptor $\gamma$ in human prostate cancer. Proc. Natl. Acad. Sci. 97: 10990-10995.

Nusse, R. and Varmus, H.E. 1982. Many tumors induced by the mouse mammary tumor virus contain a provirus integrated in the same region of the host genome. Cell 31: 99-109.

Nwankwo, J.O. and Robbins, M.E. 2001. Peroxisome proliferator-activated receptor- $\gamma$ expression in human malignant and normal brain, breast and prostate-derived cells. Prostaglandins Leukot. Essent. Fatty Acids 64: 241-245.

Olson, D.J., and Gibo, D.M. 1998. Antisense wnt-5a mimics wnt-1-mediated C57MG mammary epithelial transformation. Exp. Cell Res. 241: 134-141.

Palakurthi, S.S., Aktas, H., Grubissich, L.M., Mortensen, R.M., and Halperin, J.A. 2001. Anticancer effects of thiazolidinediones are independent of peroxisome proliferator-activated receptor $\gamma$ and mediated by inhibition of translation initiation. Cancer Res. 61: 6213-6218.

Pallas, D.C., Shahrik, L.K., Martin, B.L., Jaspers, S., Miller, T.B., Brautigan, D.L., and Roberts, T.M. 1990. Polyoma small and middle $\mathrm{T}$ antigens and SV40 small $\mathrm{t}$ antigen form stable complexes with protein phosphatase 2A. Cell 60: 167-176.

Paltoo, D., Woodson, K., Taylor, P., Albanes, D., Virtamo, J., and Tangrea, J. 2003. Pro12Ala polymorphism in the peroxisome proliferator-activated receptor- $\gamma(\operatorname{PPAR}-\gamma)$ gene and risk of prostate cancer among men in a large cancer prevention study. Cancer Lett. 191: 67-74.
Park, B.H., Vogelstein, B., and Kinzler, K.W. 2001. Genetic disruption of PPAR $\delta$ decreases the tumorigenicity of human colon cancer cells. Proc. Nat1. Acad. Sci. 98: 2598-2603.

Pierce Jr., D.F., Gorska, A.E., Chytil, A., Meise, K.S., Page, D.L., Coffey Jr., R.J., and Moses, H.L. 1995. Mammary tumor suppression by transforming growth factor $\beta 1$ transgene expression. Proc. Natl. Acad. Sci. 92: 4254-4258.

Pighetti, G.M., Novosad, W., Nicholson, C., Hitt, D.C., Hansens, C., Hollingsworth, A.B., Lerner, M.L., Brackett, D., Lightfoot, S.A., and Gimble, J.M. 2001. Therapeutic treatment of DMBA-induced mammary tumors with PPAR ligands. Anticancer Res. 21: 825-829.

Place, A.E., Suh, N., Williams, C.R., Risingsong, R., Honda, T., Honda, Y., Gribble, G.W., Leesnitzer, L.M., Stimmel, J.B., Willson, T.M., et al. 2003. The novel synthetic triterpenoid, CDDO-imidazole, inhibits inflammatory response and tumor growth in vivo. Clin. Cancer Res. 9: 2798-2806.

Polakis, P. 2000. Wnt signaling and cancer. Genes \& Dev. 14: 1837-1851.

Ratcliffe, M.J., Itoh, K., and Sokol, S.Y. 2000. A positive role for the PP2A catalytic subunit in Wnt signal transduction. $J$. Biol. Chem. 275: 35680-35683.

Rayet, B. and Gelinas, C. 1999. Aberrant rel/nfkb genes and activity in human cancer. Oncogene 18: 6938-6947.

Roberts-Thomson, S.J. and Snyderwine, E.G. 2000. Characterization of peroxisome proliferator-activated receptor $\alpha$ in normal rat mammary gland and 2-amino-l-methyl-6-phenylimidazo[4,5-b]pyridine-induced mammary gland tumors from rats fed high and low fat diets. Toxicol. Lett. 118: 7986.

Rosen, E.D. and Spiegelman, B.M. 2001. PPAR $\gamma$ : A nuclear regulator of metabolism, differentiation, and cell growth. J. Biol. Chem. 276: 37731-37734.

Rosenfeld, J.M., Vargas, R., Xie, W., and Evans, R.M. 2003. Genetic profiling defines the xenobiotic gene network controlled by the nuclear receptor Pregnane X Receptor. Mol. Endocr. 17: 1268-1282.

Saez, E., Tontonoz, P., Nelson, M.C., Alvarez, J.G., Ming, U.T., Baird, S.M., Thomazy, V.A., and Evans, R.M. 1998. Activators of the nuclear receptor PPAR $\gamma$ enhance colon polyp formation. Nat. Med. 4: 1058-1061.

Sarraf, P., Mueller, E., Jones, D., King, F.J., DeAngelo, D.J., Partridge, J.B., Holden, S.A., Chen, L.B., Singer, S., Fletcher, C., et al. 1998. Differentiation and reversal of malignant changes in colon cancer through PPAR $\gamma$. Nat. Med. 4: 1046-1052.

Sarraf, P., Mueller, E., Smith, W.M., Wright, H.M., Kum, J.B., Aaltonen, L.A., de la Chapelle, A., Spiegelman, B.M., and Eng, C. 1999. Loss-of-function mutations in PPAR $\gamma$ associated with human colon cancer. Mol. Cell 3: 799-804.

Schulte-Merker, S., Hammerschmidt, M., Beuchle, D., Cho, K.W., De Robertis, E.M., and Nusslein-Volhard, C. 1994a. Expression of zebrafish goosecoid and no tail gene products in wild-type and mutant no tail embryos. Development 120: $843-852$.

Schulte-Merker, S., van Eeden, F.J., Halpern, M.E., Kimmel, C.B., and Nusslein-Volhard, C. 1994b. no tail (ntl) is the zebrafish homologue of the mouse $\mathrm{T}$ (Brachyury) gene. Development 120: 1009-1015.

Seagroves, T.N., Krnacik, S., Raught, B., Gay, J., Burgess-Beusse, B., Darlington, G.J., and Rosen, J.M. 1998. C/EBP $\beta$, but not $\mathrm{C} / \mathrm{EBP} \alpha$, is essential for ductal morphogenesis, lobuloalveolar proliferation, and functional differentiation in the mouse mammary gland. Genes \& Dev. 12: 1917-1928.

Seed, B. 1998. PPAR $\gamma$ and colorectal carcinoma: Conflicts in a nuclear family. Nat. Med. 4: 1004-1005.

Sporn, M.B., Suh, N., and Mangelsdorf, D.J. 2001. Prospects for 


\section{Saez et al.}

prevention and treatment of cancer with selective PPAR $\gamma$ modulators (SPARMs). Trends Mol. Med. 7: 395-400.

Suh, N., Wang, Y., Williams, C.R., Risingsong, R., Gilmer, T., Willson, T.M., and Sporn, M.B. 1999. A new ligand for the peroxisome proliferator-activated receptor- $\gamma$ (PPAR- $\gamma$ ), GW7845, inhibits rat mammary carcinogenesis. Cancer Res. 59: 5671-5673.

Taipale, J. and Beachy, P.A. 2001. The Hedgehog and Wnt signalling pathways in cancer. Nature 411: 349-354.

Tontonoz, P., Singer, S., Forman, B.M., Sarraf, P., Fletcher, J.A., Fletcher, C.D., Brun, R.P., Mueller, E., Altiok, S., Oppenheim, H., et al. 1997. Terminal differentiation of human liposarcoma cells induced by ligands for peroxisome proliferator-activated receptor $\gamma$ and the retinoid X receptor. Proc. Natl. Acad. Sci. 94: 237-241.

Walczak, R. and Tontonoz, P. 2002. PPARadigms and PPARadoxes. Expanding roles for PPAR $\gamma$ in the control of lipid metabolism. J. Lipid Res. 43: 177-186.

Wasan, H.S., Novelli, M., Bee, J., and Bodmer, W.F. 1997. Dietary fat influences on polyp phenotype in multiple intestinal neoplasia mice. Proc. Nat1. Acad. Sci. 94: 3308-3313.

Willson, T.M., Brown, P.J., Sternbach, D.D., and Henke, B.R. 2000. The PPARs: From orphan receptors to drug discovery. J. Med. Chem. 43: 527-550.

Zimmet, P., Alberti, K.G., and Shaw, J. 2001. Global and societal implications of the diabetes epidemic. Nature 414: 782787. 


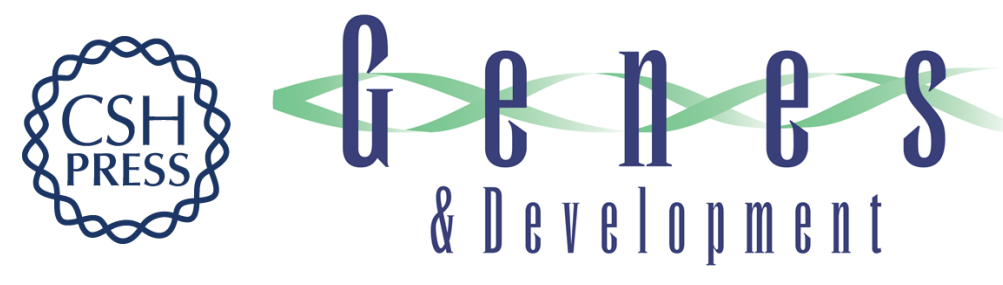

\section{PPAR $\gamma$ signaling exacerbates mammary gland tumor development}

Enrique Saez, John Rosenfeld, Antonia Livolsi, et al.

Genes Dev. 2004, 18:

Access the most recent version at doi:10.1101/gad.1167804

Supplemental

Material

References

License

Email Alerting Service
http://genesdev.cshlp.org/content/suppl/2004/02/27/18.5.528.DC1

This article cites 68 articles, 29 of which can be accessed free at: http://genesdev.cshlp.org/content/18/5/528.full.html\#ref-list-1

Receive free email alerts when new articles cite this article - sign up in the box at the top right corner of the article or click here.

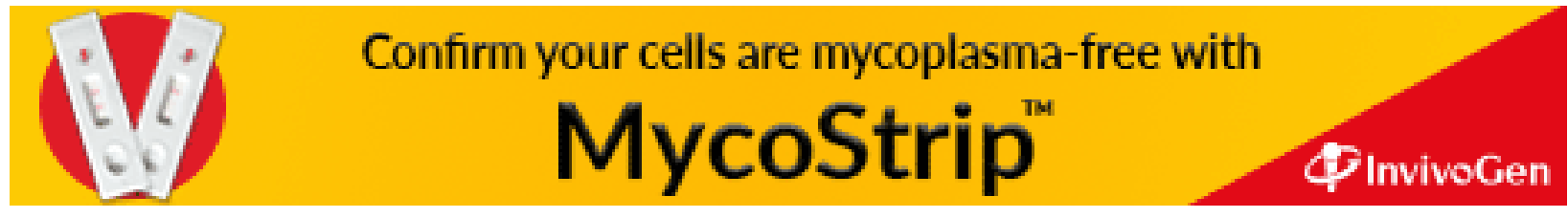

